\title{
GNAl1 Gene
}

National Cancer Institute

\section{Source}

National Cancer Institute. GNAl1 Gene. NCI Thesaurus. Code C38371.

This gene is plays a role in signal transduction and is involved in neurotransmission. 